\title{
Antimicrobial activity of petroleum ether and methanolic extracts from fruits of Seseli devenyense Simonk. and the herb of Peucedanum luxurians Tamam.
}

\author{
Jaroslaw Widelski ${ }^{1 \star}$, Agnieszka GrzegorczyK ${ }^{2}$, Anna Malm², \\ IOANNA ChinOU ${ }^{3}$, Kazimierz GŁOWNIAK ${ }^{4}$
}

\begin{abstract}
${ }^{1}$ Department Pharmacognosy with Medicinal Plant Unit, Medical University of Lublin, 1 Chodzki, 20-093, Lublin, Poland
${ }^{2}$ Department Pharmaceutical Microbiology with Laboratory of Microbiological Diagnostics, Medical University of Lublin, 1 Chodzki, 20-093, Lublin, Poland

${ }^{3}$ Department of Pharmacognosy and Chemistry of Natural Product, Faculty of Pharmacy, University of Athens, Greece

${ }^{4}$ Department of Cosmetology, University of Information Technology and Management in Rzeszow, Kielnarowa 386a, 36-020 Tyczyn, Poland
\end{abstract}

\section{ARTICLE INFO \\ Received 17 September 2015 \\ Accepted 01 October 2015}

Keywords:
Peucedanum luxurians,
Seseli devenyense,
coumarins,
antimicrobial,
Staphylococcus.

\begin{abstract}
Plants of the Apiaceae family usually contain coumarins. These are used worldwide in traditional medicine, as well as in modern therapeutics. The aim of our study was to determine the antimicrobial activity of four extracts (methanolic and petroleum ether extracts) obtained from two Apiaceae species: Seseli devenyense (fruits) and Peucedanum luxurians (herb).

The activity of the investigated extracts was tested against 7 strains of Gram+ bacteria, and 7 strains of Gram-, as well as three of yeast. The results of this show that the best activity of such extracts (specifically, by way of petroleum ether) was seen as being against Staphylococcus aureus strains.
\end{abstract}

\section{INTRODUCTION}

Coumarin compounds are representatives of a category of heterocyclic natural compounds characterized by large chemodiversity (with about 2000 reported structures) and a huge variety of pharmacological activities [4]. The genus Seseli and the genus Peucedanum are very well-known sources of all classes of coumarins (simple coumarins, pyranocoumarins and furanocoumarins). Indeed, both genera contain numerous species that have been used in folk medicine since ancient times [2] for the treatment of different diseases - including that which are infectious [6].

However, previous studies which had been focused on different species from Seseli [5] and Peucedanum [1,3], have evidenced a range of antimicrobial activity on different bacteria, including Staphylococcus auresus, Escerichia coli, Salmonella typhi and others. Hence, clarification should be made of best source and best extraction method.

\footnotetext{
* Corresponding author

e-mail: jwidelski@pharmacognosy.org
}

\section{MATERIALS AND METHODS}

Plant material. Ripe fruits of Seseli devenyense were collected in October 2014, in the Pharmacognostic Garden of the Medical University of Lublin, Poland. A voucher sample (2080) was then placed in Index Seminum Anno2014, Hortus Botanicus Universitatis Mariae CurieSkłodowska, Lublin, Poland. The plant was identified by workers of the botanical garden. The herb of Peucedanum luxurians was cultivated and collected in the Botanical Garden of Adam Mickiewicz University in Poznań (code: S_S047_008_0004_7973_S003).

Extraction. The air dried and powdered material (30 $\mathrm{g}$ of S.devenyense fruits and $30 \mathrm{~g}$ of Peucedanum luxurians herb) was extracted either with petroleum ether or methanol, in a Soxhlet appararus for 48 hours. After the evaporation of the solvents, the obtained extracts were $4,4 \mathrm{~g}$ of petroleum ether and 1,6 of methanolic extracts obtained from the fruits of S.devenyense and 3,8 g, and 2,0 g, respectively, gained from Peucedanum luxurians herb.

Microorganisms. The in vitro antimicrobial activity of the extracts obtained from Paucedanum luxurians and Seseli devenyense were tested against a panel of microorganisms 
from American Type Culture Collection (ATCC). This consisted of: Gram-positive bacteria (Staphylococcus aureus ATCC 6538, Staphylococcus aureus ATCC 43300, Staphylococcus aureus ATCC 25923, Staphylococcus epidermidis ATCC 12228, Micrococcus luteus ATCC 10240, Bacillus subtilis ATCC 6633, Bacillus cereus ATCC 10876); the Gram-negative bacteria (Escherichia coli ATCC 3521, Escherichia coli ATCC 25922, Salmonella typhimurium ATCC 14028, Bordetella bronchiseptica ATCC 4617, Klebsiella pneumoniae ATCC 13883, Pseudomonas aeruginosa ATCC 27853, Proteus mirabilis ATCC 12453); and the yeasts (Candida parapsilosis ATCC 22019, Candida albicans ATCC 2091, Candida albicans ATCC 10231).

Antimicrobial susceptibility testing. The in vitro antimicrobial activity of the extracts obtained from $P$. luxurians and $S$. devenyense were assessed by using the micro-dilution broth method in 96-well microtitrate plates against all the aforementioned bacteria and the yeasts. This enabled an estimation of MIC (minimum inhibitory concentration), MBC (minimum bactericidal concentration) and MFC (minimum fungicidal concentration).

Microdilution Test. Mueller-Hinton broth (for Grampositive and Gram-negative bacteria) and Mueller-Hinton broth with $2 \%$ glucose (for yeasts) were used to determine antibacterial and antifungal activity, respectively. All the extracts were diluted serially.

Lab procedure. The tested extracts were initially dissolved in dimethyl sulfoxide (DMSO) to a concentration of $10 \mathrm{mg} / \mathrm{ml}$. The first stock solutions $(1 \mathrm{mg} / \mathrm{ml})$ of these extracts were prepared in MHB and MHB2\%. Then, in the same media, a serial twofold dilution was made in order to obtained final concentrations of samples ranging from 0.016 to $0.5 \mathrm{mg} / \mathrm{ml}$. The colonies of each strain were resuspended in sterile physiological saline to provide an optical density equal to $0.5 \mathrm{McF}$ arland. Then the final concentration of inoculum was adjusted to approximately $10^{6} \mathrm{CFU} / \mathrm{ml}$ with sterile MHB, and $10^{4} \mathrm{CFU} / \mathrm{ml}$ with sterile $\mathrm{MHB} 2 \%$ in case of bacteria and yeasts, respectively. The last two wells were positive and negative controls. The positive control was inoculated with a bacterial and yeast suspension only, while the negative well was left blank without inoculation. The MICs of all extracts were recorded as the lowest concentration where no viability was observed in the wells of 96 -well microtitrate plates after incubation at $35^{\circ} \mathrm{C}$ (in case bacteria) and $30^{\circ} \mathrm{C}$ (in case yeasts) in ambient air for $24 \mathrm{~h}$. After determination of the MICs, MBCs and MFCs were assessed by spreading $5 \mu \mathrm{l}$ suspension from each well showing no growth onto Mueller-Hinton Agar (for bacteria), and Mueller-Hinton Agar with 2\% glucose (for yeasts). The data obtained are presented Table 1. The results of MICs were checked by way of the spectrophotometry of absorbance at $580 \mathrm{~nm}$, using a Absorbance Microplate Reader EL $\times 800$ (BioTek Instruments, Inc., USA). All experiments were performed in triplicate.

\section{RESULTS}

\section{Antimicrobial Activity}

Table 1. The antimicrobial activity of the investigated extracts

\begin{tabular}{|c|c|c|c|c|}
\hline Microorganism & 1 & 2 & 3 & 4 \\
\hline Gram-positive bacteria & \multicolumn{4}{|c|}{$\begin{array}{l}\text { MIC; MBC } \\
(\mathrm{MBC} / \mathrm{MIC})\end{array}$} \\
\hline S. aureus ATCC 6538 & $\begin{array}{l}>1 ;>1 \\
(\mathrm{Nd} \mathrm{a})\end{array}$ & $\begin{array}{c}0.25 ; 1 \\
(4)\end{array}$ & $\begin{array}{c}0.25 ;>1 \\
(>4)\end{array}$ & $\begin{array}{c}0.25 ;>1 \\
(>4)\end{array}$ \\
\hline S. aureus ATCC 43300 & $\begin{array}{l}>1 ;>1 \\
(\mathrm{Nd})\end{array}$ & $\begin{array}{c}0.5 ; 1 \\
(2)\end{array}$ & $\begin{array}{c}>1 ;>1 \\
(\mathrm{Nd})\end{array}$ & $\begin{array}{c}>1 ;>1 \\
(\mathrm{Nd})\end{array}$ \\
\hline S. aureus ATCC 25923 & $\begin{array}{l}>1 ;>1 \\
(\mathrm{Nd})\end{array}$ & $\begin{array}{c}1 ;>1 \\
(>1)\end{array}$ & $\begin{array}{l}>1 ;>1 \\
(\mathrm{Nd})\end{array}$ & $\begin{array}{c}1 ;>1 \\
(>1)\end{array}$ \\
\hline S. epidermidis ATCC 12228 & $\begin{array}{l}>1 ;>1 \\
(\mathrm{Nd})\end{array}$ & $\begin{array}{c}1 ;>1 \\
(>1)\end{array}$ & $\begin{array}{l}>1 ;>1 \\
(\mathrm{Nd})\end{array}$ & $\begin{array}{l}>1 ;>1 \\
(\mathrm{Nd})\end{array}$ \\
\hline B. subtilis ATCC 6633 & $\begin{array}{l}>1 ;>1 \\
(\mathrm{Nd})\end{array}$ & $\begin{array}{c}1 ;>1 \\
(>1)\end{array}$ & $\begin{array}{l}>1 ;>1 \\
(\mathrm{Nd})\end{array}$ & $\begin{array}{l}>1 ;>1 \\
(\mathrm{Nd})\end{array}$ \\
\hline B. cereus ATCC 10876 & $\begin{array}{l}>1 ;>1 \\
(\mathrm{Nd})\end{array}$ & $\begin{array}{c}1 ;>1 \\
(>1)\end{array}$ & $\begin{array}{l}>1 ;>1 \\
(\mathrm{Nd})\end{array}$ & $\begin{array}{l}>1 ;>1 \\
(\mathrm{Nd})\end{array}$ \\
\hline M. luteus ATCC 10240 & $\begin{array}{l}>1 ;>1 \\
(\mathrm{Nd})\end{array}$ & $\begin{array}{c}0.25 ; 0.5 \\
(2)\end{array}$ & $\begin{array}{c}0.5 ;>1 \\
(>1)\end{array}$ & $\begin{array}{c}1 ;>1 \\
(>1)\end{array}$ \\
\hline Gram-negative bacteria & \multicolumn{4}{|c|}{$\begin{array}{l}\text { MIC; MBC } \\
(\mathrm{MBC} / \mathrm{MIC})\end{array}$} \\
\hline E. coli ATCC 3521 & $\begin{array}{l}>1 ;>1 \\
(\mathrm{Nd})\end{array}$ & $\begin{array}{l}>1 ;>1 \\
(\mathrm{Nd})\end{array}$ & $\begin{array}{c}>1 ;>1 \\
(\mathrm{Nd})\end{array}$ & $\begin{array}{c}>1 ;>1 \\
(\mathrm{Nd})\end{array}$ \\
\hline E. coli ATCC 25922 & $\begin{array}{c}>1 ;>1 \\
(\mathrm{Nd})\end{array}$ & $\begin{array}{c}>1 ;>1 \\
(\mathrm{Nd})\end{array}$ & $\begin{array}{l}>1 ;>1 \\
(\mathrm{Nd})\end{array}$ & $\begin{array}{c}>1 ;>1 \\
(\mathrm{Nd})\end{array}$ \\
\hline S. typhimurium ATCC 14028 & $\begin{array}{l}>1 ;>1 \\
(\mathrm{Nd})\end{array}$ & $\begin{array}{l}>1 ;>1 \\
(\mathrm{Nd})\end{array}$ & $\begin{array}{l}>1 ;>1 \\
(\mathrm{Nd})\end{array}$ & $\begin{array}{l}>1 ;>1 \\
(\mathrm{Nd})\end{array}$ \\
\hline B. bronchiseptica ATCC 4617 & $\begin{array}{l}>1 ;>1 \\
(\mathrm{Nd})\end{array}$ & $\begin{array}{c}1 ;>1 \\
(>1)\end{array}$ & $\begin{array}{l}>1 ;>1 \\
(\mathrm{Nd})\end{array}$ & $\begin{array}{l}>1 ;>1 \\
(\mathrm{Nd})\end{array}$ \\
\hline K. pneumoniae ATCC 13883 & $\begin{array}{l}>1 ;>1 \\
(\mathrm{Nd})\end{array}$ & $\begin{array}{l}>1 ;>1 \\
(\mathrm{Nd})\end{array}$ & $\begin{array}{l}>1 ;>1 \\
(\mathrm{Nd})\end{array}$ & $\begin{array}{l}>1 ;>1 \\
(\mathrm{Nd})\end{array}$ \\
\hline P. mirabilis ATCC 12453 & $\begin{array}{l}>1 ;>1 \\
(\mathrm{Nd})\end{array}$ & $\begin{array}{l}>1 ;>1 \\
(\mathrm{Nd})\end{array}$ & $\begin{array}{l}>1 ;>1 \\
(\mathrm{Nd})\end{array}$ & $\begin{array}{l}>1 ;>1 \\
(\mathrm{Nd})\end{array}$ \\
\hline P. aeruginosa ATCC 9027 & $\begin{array}{l}>1 ;>1 \\
(\mathrm{Nd})\end{array}$ & $\begin{array}{c}>1 ;>1 \\
(\mathrm{Nd})\end{array}$ & $\begin{array}{c}>1 ;>1 \\
(\mathrm{Nd})\end{array}$ & $\begin{array}{l}>1 ;>1 \\
(\mathrm{Nd})\end{array}$ \\
\hline Yeasts & \multicolumn{4}{|c|}{$\begin{array}{l}\text { MIC; MFC } \\
\text { (MFC/MIC) }\end{array}$} \\
\hline C. parapsilosis ATCC 22019 & $\begin{array}{l}>1 ;>1 \\
(\mathrm{Nd})\end{array}$ & $\begin{array}{c}>1 ;>1 \\
(\mathrm{Nd})\end{array}$ & $\begin{array}{c}0.25 ;>1 \\
(>4)\end{array}$ & $\begin{array}{c}1 ;>1 \\
(>1)\end{array}$ \\
\hline C. albicans ATCC 2091 & $\begin{array}{c}1 ;>1 \\
(>1)\end{array}$ & $\begin{array}{l}>1 ;>1 \\
(\mathrm{Nd})\end{array}$ & $\begin{array}{c}>1 ;>1 \\
(\mathrm{Nd})\end{array}$ & $\begin{array}{c}1 ;>1 \\
(>1)\end{array}$ \\
\hline C. albicans ATCC 10231 & $\begin{array}{c}>1 ;>1 \\
(\mathrm{Nd})\end{array}$ & $\begin{array}{c}>1 ;>1 \\
(\mathrm{Nd})\end{array}$ & $\begin{array}{c}>1 ;>1 \\
(\mathrm{Nd})\end{array}$ & $\begin{array}{c}1 ;>1 \\
(>1)\end{array}$ \\
\hline
\end{tabular}

$\mathrm{Nd}=$ Not determined; $1 \mathrm{mg} / \mathrm{l}$ - mild activity; $0.5 \mathrm{mg} / \mathrm{l}$ - moderate

activity; $0.25 \mathrm{mg} / \mathrm{l}$ - moderate activity

1. Peucedanum luxurians - herb (methanolic extract)

2. Peucedanum luxurians - herb (dichlorometane extract) (dichlorometanol)

3. Seseli devenyense - fruits (methanolic extract)

4. Seseli devenyense - fruits (dichlorometane extract)

\section{DISCUSSION}

The methanol extract obtained from the herbs and fruits of $P$. luxurians showed no activity in the case of Grampositive and Gram-negative bacteria and yeasts, while mild activity $(1 \mathrm{mg} / \mathrm{ml})$ was observed for C. albicans ATCC 2091.

However, the dichloromethane extracts obtained from the herbaceous tissues of $P$. luxurians exhibited an inhibitory effect, with MIC values ranging from 0.25 to $1 \mathrm{mg} / \mathrm{ml}$ in the case of Gram-positive bacteria. Of these, most sensitive were S. aureus ATCC 6538 and M. luteus ATCC 10240, with $\mathrm{MIC}=0.25 \mathrm{mg} / \mathrm{ml}$. Furthermore, mild activity $(1 \mathrm{mg} / \mathrm{ml})$ was observed for B. bronchiseptica ATCC 4617.

The dichloromethane extracts obtained from the fruits of P. luxurians showed no activity in the case of Gram-negative bacteria, while moderate activity $(0.5 \mathrm{mg} / \mathrm{ml})$ was observed for S. aureus ATCC 6538 and M. luteus ATCC 10240. In addition, mild activity $(1 \mathrm{mg} / \mathrm{ml})$ was observed for both strains $C$. albicans ATCC. 
As shown in Table 1, the MIC value of the examined methanol extract gained from the fruits of $S$. devenyense against Gram-positive bacteria was 0.25 and $0.5 \mathrm{mg} / \mathrm{ml}$ for S. aureus ATCC 6538 and M. luteus ATCC 10240, respectively. What is more, moderate activity $(0.25 \mathrm{mg} / \mathrm{ml})$ was observed for $C$. parapsilosis ATCC 22019.

The dichloromethane extracts obtained from fruits of $S$. devenyense showed moderate activity $(0.25 \mathrm{mg} / \mathrm{ml})$ in case of $S$. aureus ATCC 6538. Furthermore, mild activity $(1 \mathrm{mg} / \mathrm{ml})$ was observed for $S$. aureus ATCC 25923, M. luteus ATCC 10240 and yeasts.

These data indicate that the extracts possessed some antibacterial and antifungal properties against Gram-positive bacteria and yeasts. However, our data indicate that these tested extracts exhibited no in vitro antibacterial activity among Gram-negative bacteria. The MBC of most extracts against Gram-positive bacteria and Gram-negative bacteria was $<1 \mathrm{mg} / \mathrm{ml}$; the MBC of dichloromethane extracts obtained from the herbaceous tissues of $P$. luxurians ranged from 0.5 to $1 \mathrm{mg} / \mathrm{ml}$, in the case of $M$. luteus ATCC 10240, S. aureus ATCC 6538 and S. aureus ATCC 43300. In addition, the $\mathrm{MBC}$ of dichloromethane extracts obtained from the fruits of $P$. luxurians was $0.5 \mathrm{mg} / \mathrm{ml}$ in regard to M. luteus ATCC 10240. Finally, the MFC of all extracts against yeasts was $>1 \mathrm{mg} / \mathrm{ml}$.

\section{CONCLUSIONS}

In our study, the activity of the tested extracts was observed at high concentrations, and their bactericidal effect appears promising. Our results indicate that the non-polar fraction from Peucedanum luxurians and from Seseli devenyense can be regarded as potentially useful agents in the treatment of bacterial infection as induced by Staphylococcus. The results of our study are comparable to studies of other species belonging to the genera Seseli (the antibacterial activity of Seseli libanotis [5]) and Peucedanum (the activity of Peucedanum praeruptorum [1] and Peucedanum austriacum [3]) from the Apiaceae family. It is also worth mentioning the fact that some of the natural coumarins have RMA (resistance-modifying agents) potential, which enables antibiotics to exert an enhanced antibacterial effect (as RMA reverses the resistance mechanism in MRSA) [7]. Hence, it is recommended that attempts be made to extract the active compounds responsible for this kind of activity.

\section{ACKNOWLEDGMENTS}

The authors would like to express gratitude to the Director and employees of the Botanical Garden, UMA in Poznan for assistance in obtaining plant material.

\section{REFERENCES}

1. Chen B., Wang M., Liu J.: Chemical constituents of the volatile oil from the roots of Peucedanum praeruptorum and antibacterial activity. Redai Yaredai Zhiwu Xuebao, 10, 2002, 366

2. Dioskurides (2002). De Materia Medica. Codex Neapolitanus Graecus of National Library of Naples. Athens. Militos Press,pp. 215-216

3. Jovanovic O. P., Zlatkovic B. K., Simonovic S. R., Djordjevic A. S., Palic I. R., Stojanovic G. S.: Chemical composition and antibacterial activity essential oils isolated from leaves and fruits of Peucedanum austriacum (Jacq.) W.D.J. Koch. JEOR 25, 129, 2013

4. Murray R.D.H. (2002). Progress in the Chemistry of Organic Natural Products. Herz W., Falk H., Kirby G.W., Moore R.E. (editors). Wien, vol. 83, pp. 1-529

5. Ozturk S.Ercisli S.: Chemical composition and in vivo antibacterial activity of Seseli libanotis. World J Microb. Biotechn., 22, 261, 2006.

6. Skalicka-Woźniak K., Los R., Głowniak K., Malm A.: Antimicrobial activity of fatty acids from fruits of Peucedanum cervaria and $P$. alsaticum. Chem Biodiv, 7, 2748, 2010

7. Smyth T., Ramachandran V.N., Smyth W.F.: A study of antimicrobial activity of selected naturally occuring and synthetic coumarins. Int J Antimicrob Agents, 33, 421, 2009. 